\title{
Akut koroner sendromlu hastalarda endotelyal progenitör hücre sayımı
}

\section{Endothelial progenitor cell count in patients with acute coronary syndrome}

\author{
Ahmet Karagöz*, İbrahim Kocaoğlu, Özgül Uçar, Ender Örnek, Serkan Serdar, \\ Emre Ertürk, Begüm Yetiş Sayın
}

Kardiyoloji Kliniği (Dr. A. Karagöz, Dr. S. Serdar, Dr. E. Ertürk, Dr. B. Y. Sayın), Giresun Prof. Dr. Atilla İlhan Özdemir Devlet Hastanesi, TR-28100 Giresun, Kardiyoloji Kliniği (Dr. İ. Kocaoğlu), Türkiye Yüksek İhtisas Hastanesi, TR-06230 Ankara, Kardiyoloji Kliniği (Doç. Dr. Ö. Uçar, Doç. Dr. E. Örnek), Ankara Numune Eğitim ve Araştırma Hastanesi, TR-06100 Ankara

\begin{abstract}
Özet
Amaç. Endotelyal progenitör hücreler mekanik olarak endotel hücrelerinin hasarlanarak uzaklaştırılması ile ya da sitokinlerin uyarımı ile kemik iliğinden periferik kana göç ederek hasar bölgesindeki endotel hücrelerinin yerine geçerek ilgili alanı onarmaktadırlar. Daha önce bu hücrelerin stabil koroner arter hastalarında kronik süreçte azaldığı, akut koroner sendrom hastalarında ise sayıca arttı̆̆g gösterilmişti. Bu çalıșmanın amacı akut koroner sendrom tanısı ile koroner yoğun bakım ünitesine yatırılan hastalarda hastalığın alt grupları arasında (ST elevasyonlu miyokard infarktüsü, ST elevasyonlu olmayan miyokard infarktüsü ve anstabil angina pektoris ) endotelyal progenitor hücre sayıları bakımından fark olup olmadığının incelenmesidir. Yöntem. Çalışma verileri iki aşamada analiz edildi. İlk aşamada akut koroner sendrom sınıflamasında yer alan üç alt grup (n=112) arasında endotelyal progenitor hücre sayıları arasında fark olup olmadığı araştırıldı. Analizin ikinci aşamasında ise unstabil angına pektoris ön tanısı ile hospitalize edilen fakat enzim yüksekliği olmayan, koroner anjiografi ve ekokardiyografileri normal olarak saptanan 13 hasta daha değerlendirmeye alındı. Hastalar, enzim yüksekliği saptanmayan yani kardiyak hasarın olmadığı unstabil angına pektoris hastaları ve koroner anjiografide normal koroner arterlerin saptandığı hastalar bir grup (Grup A, n=41), kardiyak enzim yüksekliği saptanan yani kardiyak hasarın dökümente olduğu, ST elevasyonlu miyokard enfarktüsü ve ST elevasyonsuz miyokard enfarktüsü hastaları diğer bir grup (Grup B, n=84) olmak üzere iki gruba ayrıldı ve bu iki grup arasında endotelyal progenitor hücreler sayıları açısından fark olup olmadığına bakıldı. Bulgular. Çalışma bulgularımız iç grup arasında arasında endotelyal progenitor hücre sayısı açısından istatistiksel olarak anlamlı farklılık olmadığını göstermiştir (sırasıyla 3,87 $\pm 2,74,5,46 \pm$ $6,38$ ve $3,95 \pm 2,94, p=0,232)$. Yapilan istatistiksel analiz sonucunda Grup A ve Grup B arasında da endotelya progenitor hücre sayıları açısından anlamlı farklılık saptanmadı $(3,89 \pm 2,81$ 'e karşılık $4,80 \pm 5,22 ; \mathrm{p}=0,302)$. Sonuç. Bu bilgiler 1şı̆̆ında, tedavi modalitelerindeki gelişmelere rağmen halen tedavi direnci sorununun gündemde olduğu koroner arter hastalı̆ğnda bu hücrelerin terapötik yaklaşımlarda kullanılması için kemik iliğinde ve periferik kandaki sayı ve fonksiyonları, hedef dokudaki etkileri ve bu hücreleri etkileyen düzenleyici faktörler konusunda daha ileri klinik çalışmalara ihtiyaç duyulmaktadır.
\end{abstract}

Anahtar sözcükler: Endotelyal progenitör hücre, akut koroner sendrom, ateroskleroz

\begin{abstract}
Aim. Endothelial progenitor cells repair related region by removal of damaged endothelial cells mechanically or replacing endothelial cells via migration from bone marrow to peripheric blood pool with stimulus of cytokines. Previously, it has been shown that number of these cells decrease in chronic stage of stable coronary heart disease, whereas they increase in number in acute coronary syndromes. The aim of this study is to investigate the difference in the number of endothelial progenitor cells among subgroups of acute coronary syndrome (ST elevation myocardial infarction, non-ST elevation myocardial infarction and unstable angina pectoris ) in patients hospitalized in coronary intensive care unit. Method. The study data were analysed in two steps. In the first step, it has been investigated whether there were any differences regarding endothelial progenitor cell count among three subgroups of acute coronary syndrome $(n=112)$. In the second step, a further 13 patients who were hospitalized with a prediagnosis of unstabil angina
\end{abstract}


pectoris and subsequently reported to have normal echocardiography and coronary angiography were also enrolled. The patients were divided into two groups; the patients with unstabil angina pectoris of whom no increase in cardiac enzymes detected indicating the absence of any cardiac damage and patients with normal coronary angiography findings constituted the first group (Grup $\mathrm{A}, \mathrm{n}=41$ ) and the patients with ST elevation myocardial infarction and non-ST elevation myocardial infarction of whom an increase in cardiac enzymes detected indicating a documented cardiac damage constituted the second group (Grup B, n=84). We investigated whether there were any differences regarding endothelial progenitor cell count between these two groups. Results. Our results indicate that the number of endothelial progenitor cells did not differ significantly among these three groups in the first step $(3.87 \pm 2.74,5.46 \pm 6.38$ and $3.95 \pm 2.94$, respectively; $\mathrm{p}=0.232$ ). The results of the statistical analysis also revealed no differences between Grup A and Grup B regarding EPC counts $(3.89 \pm 2.81$ vs $4.80 \pm 5.22$; $\mathrm{p}=0.302)$. Conclusion. In the light of these data, in coronary heart disease in which resistance to treatment is a topical problem despite improvements in therapeutic modalities, further clinical studies are needed about the number and the functions of these cells in the bone marrow and peripheric blood, their effects on target tissues and the factors regulating them, for theurapeutic use of these cells.

Keywords: Endothelial progenitor cell, acute coronary syndrome, atherosclerosis

Geliş tarihi/Received: 26 Ağustos 2012; Kabul tarihi/Accepted: 20 Şubat 2013

\section{*İletişim adresi:}

Dr. Ahmet Karagöz, Kardiyoloji Kliniği, Giresun Prof. Dr. Atilla İlhan Özdemir Devlet Hastanesi, TR-28100 Giresun. E-posta: drahmetkgz@ hotmail.com

\section{Giriş}

Koroner arter hastalığı (KAH) tüm dünyada başta gelen ölüm nedenlerindendir. Ülkemizde de koroner arter hastalığı ölüm nedenleri arasında ilk sırada yer almakta olup bu konuda Avrupa ülkeleri arasında da ilk sıraları paylaştığımız bilinmektedir [1-3].

Vasküler sistemde uzun bir süredir hasarlı ve kaybedilen endotel hücrelerinin sadece komşu endotel hücreleri tarafından yenilenebileceğine inanılmakta idi [4]. Fakat periferik kanda kök hücre ve endotel hücresi belirteçlerini birlikte bulunduran endotelyal progenitör (öncül) hücrelerin (EPC) saptanması, onların endotelyal fenotipe dönüşebildiğinin gösterilmesi ve vasküler onarımdaki rollerinin ortaya koyulması ile bu görüş değişmiştir [5-8]. Diyabetes mellitus (DM), yaş, hiperlipidemi ve sigara gibi kardiyovasküler risk faktörleri sistemik dolaşımdaki EPC'lerin sayısı ve fonksiyonlarını bozucu yönde etkilemektedir [9-16]. Ateroskleroz gelişiminde bu ilişkinin önemi vurgulanmaktadır. EPC ile endotel disfonksiyonu ve kardiyovasküler olayların ters ilişkili olduğu gösterilmiştir [17]. Bu hücrelerin kanda sayıca azalmaları, yapım ya da kemik iliğinden mobilizasyonlarının azalması, vasküler sistemdeki artmış kullanımı ve azalmış yaşam süreleri ile ilişkili olabilir.

$\mathrm{Bu}$ çalışmanın amacı, akut koroner sendrom tanısı ile koroner yoğun bakım ünitesine yatırılan hastalarda hastalı̆̆ın alt grupları arasında EPC sayıları bakımından fark olup olmadığının incelenmesidir.

\section{Gereç ve yöntem}

Çalışmamız Ankara Numune Eğitim ve Araştırma Hastanesi Kardiyoloji Kliniği’nde yürütülmüş, kök hücre sayımları ise Erişkin Hematoloji Sitometri Laboratuvarında yapılmıştır. Eylül 2010-Nisan 2011 tarihleri arasında hastanemiz acil servisine gögüs ağrısı ile başvuran ve koroner yoğun bakım ünitesine akut koroner sendrom tanısı ile yatırılan, yaşları 34 ile 75 arasında değişen (ortalama yaş 57,93 \pm 10,62) 125 hasta çalışmaya alınmıştır. Tipik gögüs ağrısı ile başvurup elektrokardiyografide (EKG) ardışık iki derivasyonda ST elevasyonu ve kardiyak enzim yüksekliği saptanan hastalar ST elevasyonlu myokard infarktüsü (STEMI), tipik göğüs ağrı ile başvurup EKG de ST 
elevasyonu saptanmayan fakat ST segment ve T dalga değişiklikleri ile birlikte kardiyak enzim yüksekliği gözlenen hastalar ST elevasyonsuz myokard infarktüsü (NSTEMI), son 24 saat içinde en az 15 dakika süren tipik göğüs ağrısı ile başvuran, EKG'de en az iki ardışık derivasyonda ST segment ve T dalga değişiklikleri izlenen ve kardiyak enzim yüksekliği saptanmayan hastalar anstabil angina pektoris (USAP) olarak tanımlanmıştır. Tipik göğüs ağrısı nedeni ile hospitalize edilen fakat daha sonra yapılan koroner anjiografide normal koroner arterler saptanan 13 hasta bu tanımlamanın dışına alınmıştır. İlk aşamada akut koroner sendromla başvuran hastalar STEMI $(n=35)$, NSTEMI $(n=49)$ ve USAP ( $n=28)$ olarak gruplandırılmış ve bu üç grup önce temel karakteristik özellikler, daha sonra ise EPC sayıları açısından karşılaştırılmıştır. İkinci aşamada ise USAP $(n=28)$ tanısı konulan (kardiyak enzim yüksekliği saptanmamış, koroner anjiografide lezyon saptanan) hastalar ile akut koroner sendrom tanısı ile koroner yoğun bakım ünitesine yatırılmış fakat enzim yüksekliği saptanmamış ve yapılan koroner anjiografide normal koroner arterler saptanan $(n=13)$, yani herhangi bir kardiyak hasar saptanmayan hastalar birinci grup (Grup A, $n=41)$, STEMI $(n=35)$ ve NSTEMI $(n=49)$ tanis1 konulan yani kardiyak hasar dokümente edilmiş hastalar ise ikinci grup (Grup B, n=84), olarak değerlendirilmiş ve iki alt grup arasında önce temel karakteristik özellikler sonra da EPC sayıları karşılaştırılmıştır. Tüm hastalardan çalışma öncesi bilgilendirilmiş onam formu alınmıştır. Çalışmaya alınan tüm hastaların ekokardiyografileri hastanemiz ekokardiyografi laboratuarında, koroner anjiografileri ise hastanemiz kateter laboratuvarında yapılmıştır. Çalışma protokolü Ankara Numune Eğitim Araştırma Hastanesi Yerel Etik Kurulu'nun 15/09/2010 tarih ve 2010-023 say1l karar1 ile onaylanmıştır.

$\mathrm{Bu}$ çalışma prospektif tarzda planlanarak yapıldı. Bütün hastaların fizik muayeneleri yapıldı ve demografik özellikleri, kardiyovasküler risk faktörleri ve kullandıkları ilaçlar kaydedildi. Açlık kan şekeri düzeyi $126 \mathrm{mg} / \mathrm{dl}$ ve üstü olan veya oral antidiyabetik ilaç ve insülin kullanan hastalarda DM olduğu; sistolik kan basinc1 $140 \mathrm{mmHg}$ ve üstü, diyastolik kan basınc1 $90 \mathrm{mmHg}$ ve üstü olan veya antihipertansif ilaç kullanan hastalarda hipertansiyon (HT) olduğu kabul edildi. Çalışmaya dahil edilme kriteri olarak akut koroner sendrom tanısı ile koroner yoğun bakım ünitesine yatırılmış olmak ve çalışmanın yapılması için hastanın yazılı, bilgilendirilmiş onam vermiş olması belirlendi. Yetmiş beş yaşın üzerinde olmak, inme, aktif infeksiyon ya da inflamasyon (vaskülitler ve otoimmün hastalıklar dahil), hematolojik hastalıklar, bilinen malignite varlığı, renal yetmezlik (diyaliz programında olanlar), orta-ciddi kalp kapak hastalığ olması da dışlanma kriterleri idi.

Çalışma hastalarından serviste rutin olarak çalışılan tam kan ve biyokimya dışında, akut koroner sendrom tanısı ile yattıktan hemen sonra ve tedaviye başlanmadan önce periferik kan örnekleri 4 ml'lik K3 EDTA'lı tüplere (Becton Dickinson) alındı ve en geç 2 saat içinde çalışıldı. EPC işaretlemesinde kullanılan monoklonal antikorlar (MoAb) eBiosience firmasindan elde edildi. Bunlar CD45 PERCP (peridinin chlorophyll protein), CD133 PE (phycoerythrin), CD34 FITC (fluorescein isothiocyanate) idi. Analiz sirasinda ilk olarak debri, ölü hücre ve trombositler seçilerek dışlandı. Daha sonra CD45+ olan hematopoetik hücreler dişlandı ve CD34bright CD45dim CD133+ hücreler EPC olarak tanımland.

$\mathrm{EPC}$ mutlak sayıs1 $=(\% \mathrm{EPC} \mathrm{X}$ beyaz küre sayıs1 $) / 100$ formülü ile hesaplandı [18].

\section{Ateroskleroz varlığı, ciddiyeti ve yaygınlığının değerlendirilmesi}

Ateroskleroz varlığı ve lezyon ciddiyeti görsel olarak değerlendirildi, yaygınlığ 1 ise Gensini skorlamasına göre belirlendi [19]. Bu skorlama ile anjiyografik stenoz derecesine göre; \%0-25 arası darlık için 1 puan, $\% 25-50$ arası darlık için 2 puan, $\% 50-75$ arası darlık için 4 puan, \%75-90 arası darlık için 8 puan, \%90-99 arası darlık için 16 puan, \%100 tam tıkalı lezyon için 32 puan verildi. Daha sonra ana koroner arter ve her bir segment için tanımlanmış olan sabit katsayı ile bu değer çarpıldı ve her damardan elde edilen sonuçlar toplandi. 


\section{İstatistiksel yöntem}

Verilerin analizi SPSS 15.0 istatistik paket programı kullanılarak yapıldı. Veriler değerlendirilirken frekans dağılımları, ortalamaları, standart sapmaları, yüzde değerleri, çapraz tablolar kullanıldı. Kategorik karşılaştırmalar, Pearson ki-kare veya Yates ki-kare testleri kullanılarak yapıldı. Araştırmada, gruplar arasında fark olup olmadığını karşılaştırmak için Independent Samples $\mathrm{T}$ testi ve One-Way Anova testi kullanıldı. Gruplar arasında fark bulunduğu durumlarda, farkın hangi gruplar arasında olduğunu bulmak için Tukey HSD ve LSD testi uygulandı. İhtimali (P) $\alpha=0,05$ 'ten küçük olan değerler önemli ve gruplar arasında fark vardır, büyük olan değerler önemsiz ve gruplar arasında fark yoktur, şeklinde kabul edildi.

\section{Bulgular}

Toplam 112 hastanın incelendiği ilk aşamada, üç grup arasında EPC sayısını etkileyebilecek faktörler tablo 1'de, başvuru anındaki EPC sayıları ise tablo 2'de gösterilmektedir. Tablo 1'de gösterildiği gibi bu değişkenlerden DM sıklı̆̆ STEMI grubunda daha az bulunmuş $(p=0,014)$. HsCRP değeri USAP grubunda $(p=0,011)$ HDL değeri ise STEMI grubunda anlamlı olarak daha düşüktür $(\mathrm{p}=0,035)$. Beklendiği üzere gensini skorlaması USAP grubunda daha düşük $(\mathrm{p}=0,001)$, EF ise daha yüksektir $(p=0,009)$. Diğer faktörlerin her üç grupta benzer olduğu görülmüştür. Yapılan istatistiksel değerlendirmede STEMI, NSTEMI ve USAP grupları arasında EPC sayıları açısından anlamlı fark bulunmamıştır ( $\mathrm{p}=0,232)$.

Tablo 1. Bazal karakteristik özellikler.

\begin{tabular}{|c|c|c|c|c|c|c|c|c|}
\hline & & \multicolumn{2}{|c|}{$\begin{array}{l}\text { Grup I* } \\
(n=35)\end{array}$} & \multicolumn{2}{|c|}{$\begin{array}{l}\text { Grup II** } \\
(n=49)\end{array}$} & \multicolumn{2}{|c|}{$\begin{array}{l}\text { Grup III*** } \\
(\mathbf{n}=\mathbf{2 8})\end{array}$} & $\mathbf{P}$ \\
\hline Yaş (Y1l) & & \multicolumn{2}{|c|}{$56,77 \pm 10,91$} & \multicolumn{2}{|c|}{$58,86 \pm 10,96$} & \multicolumn{2}{|c|}{$57,86 \pm 10,05$} & 0,68 \\
\hline Cinsiyet $(\mathrm{K} / \mathrm{E})$ & & \multicolumn{2}{|c|}{$6 / 29$} & \multicolumn{2}{|c|}{$16 / 33$} & \multicolumn{2}{|c|}{$7 / 21$} & 0,276 \\
\hline \multirow[t]{3}{*}{$\mathrm{HT}$} & & $\mathbf{n}$ & $\%$ & $\mathbf{n}$ & $\%$ & $\mathbf{n}$ & $\%$ & \\
\hline & Yok & 22 & 62,86 & 23 & 46,94 & 11 & 39,29 & \multirow{2}{*}{0,151} \\
\hline & Var & 13 & 37,14 & 26 & 53,06 & 17 & 60,71 & \\
\hline \multirow[t]{3}{*}{$\mathrm{DM}$} & & $\mathrm{n}$ & $\%$ & $\mathbf{n}$ & $\%$ & n & $\%$ & \\
\hline & Yok & 32 & 91,43 & 31 & 63,27 & 20 & 71,43 & \multirow{2}{*}{0,014} \\
\hline & Var & 3 & 8,57 & 18 & 36,73 & 8 & 28,57 & \\
\hline HsCRP & & \multicolumn{2}{|c|}{$2,30 \pm 2,39$} & \multicolumn{2}{|c|}{$1,85 \pm 2,26$} & \multicolumn{2}{|c|}{$0,69 \pm 1,07$} & 0,011 \\
\hline HDL & & \multicolumn{2}{|c|}{$29,95 \pm 6,77$} & \multicolumn{2}{|c|}{$33,59 \pm 9,47$} & \multicolumn{2}{|c|}{$35,29 \pm 8,14$} & 0,035 \\
\hline LDL & & \multicolumn{2}{|c|}{$\begin{array}{l}127,90 \pm \\
40,77\end{array}$} & \multicolumn{2}{|c|}{$\begin{array}{l}122,69 \pm \\
40,00\end{array}$} & \multicolumn{2}{|c|}{$\begin{array}{l}116,21 \pm \\
38,38\end{array}$} & 0,514 \\
\hline Trigliserid & & \multicolumn{2}{|c|}{$\begin{array}{l}166,06 \pm \\
106,36\end{array}$} & \multicolumn{2}{|c|}{$\begin{array}{l}173,82 \pm \\
115,55\end{array}$} & \multicolumn{2}{|c|}{$\begin{array}{l}140,11 \pm \\
72,55\end{array}$} & 0,383 \\
\hline Fibrinojen & & \multicolumn{2}{|c|}{$\begin{array}{l}314,27 \pm \\
137,98\end{array}$} & \multicolumn{2}{|c|}{$\begin{array}{l}341,55 \pm \\
98,99\end{array}$} & \multicolumn{2}{|c|}{$\begin{array}{l}325,43 \pm \\
121,88\end{array}$} & 0,571 \\
\hline \multirow[t]{3}{*}{ Sigara } & & $\mathbf{n}$ & $\%$ & $\mathbf{n}$ & $\%$ & $\mathbf{n}$ & $\%$ & \\
\hline & İçmeyen & 13 & 37,14 & 26 & 53,06 & 13 & 46,43 & 0353 \\
\hline & İçen & 22 & 62,86 & 23 & 46,94 & 15 & 53,57 & 0,353 \\
\hline Gensini skorlaması & & \multicolumn{2}{|c|}{$41,04 \pm 24,79$} & \multicolumn{2}{|c|}{$48,73 \pm 33,85$} & 23, & $3 \pm 21,41$ & 0,001 \\
\hline EF & & 45,8 & $9 \pm 11,05$ & 47 , & $6 \pm 11,77$ & 54, & $7 \pm 13,00$ & 0,009 \\
\hline LVDSÇ & & 4,9 & $\pm 0,56$ & 4,8 & $\pm 0,55$ & 4,7 & $\pm 0,59$ & 0,386 \\
\hline Sedimentasyon & & 27, & $3 \pm 22,70$ & 24 , & $2 \pm 20,00$ & 19, & $3 \pm 22,47$ & 0,32 \\
\hline Statin kullanma & & n & $\%$ & $\mathbf{n}$ & $\%$ & n & $\%$ & \\
\hline & Yok & 20 & 57,14 & 32 & 65,31 & 17 & 60,71 & \\
\hline & Var & 15 & 42,86 & 17 & 34,69 & 11 & 39,29 & 0,745 \\
\hline ACE inh./ARB kullanma & & $\mathbf{n}$ & $\%$ & $\mathbf{n}$ & $\%$ & $\mathbf{n}$ & $\%$ & \\
\hline & Yok & 23 & 65,71 & 28 & 57,14 & 19 & 67,86 & \\
\hline & Var & 12 & 34,29 & 21 & 42,86 & 9 & 32,14 & 0,578 \\
\hline
\end{tabular}

HT: Hipertansiyon, DM: Diyabetes mellitus, HsCRP: Yüksek duyarlılıklı C reaktif protein, HDL: Yüksek dansiteli lipoprotein, LDL: Düşük dansiteli lipoprotein, EF: Ejeksiyon fraksiyonu, LVDSÇ: sol ventrikül diyastol sonu çapı, ACE: Anjiotensin dönüştürücü enzim, ARB: Anjiotensin reseptör blokörü. * ST elevasyonlu myokard infarktüsü, ** ST elevasyonsuz myokard infarktüsü, *** Unstabil angina pektoris. Veriler sayı (yüzde) ve ortalama \pm standart sapma olarak gösterilmektedir. 
Tablo 2. Endotelyal progenitör hücrelerin gruplar arasında karşılaştırılması.

\begin{tabular}{lllll}
\hline & Grup I* $(\mathbf{n}=\mathbf{3 5})$ & Grup II** $(\mathbf{n = 4 9})$ & Grup III*** $(\mathbf{n = 2 8})$ & P \\
\hline EPC & $3,87 \pm 2,74$ & $5,46 \pm 6,38$ & $3,95 \pm 2,94$ & 0,232 \\
\hline EPC: & Endotelyal progenitör hücre. *STelevasyonlu myokard infarktüsü, \\
$* *$ STelevasyonsuz myokard infarktüsü, ***Anstabil angina pektoris. \\
Veriler ortalama \pm standart sapma olarak gösterilmektedir.
\end{tabular}

Yine ilk olarak EPC sayılarını etkileyen diğer faktörler iki grup arasında karşılaştıııldı. Yaş, DM veya HT varlığı, sigara kullanımı, serum trigliserit düzeyleri, statin veya anjiotensin dönüştürücü enzim (ACE) inhibitörü/anjiotensin reseptör blokörü (ARB) kullanımı açısından iki grup arasında istatistiksel olarak anlamlı fark saptanmadı. Serum düşük dansiteli lipoprotein (LDL) seviyeleri ise grup A'da anlamlı olarak daha düşük saptanırken $(0,011)$, yüksek dansiteli lipoprotein (HDL) değeri grup A'da daha yüksektir $(\mathrm{p}=0,031)$. EPC'i etkileyen faktörlerin ve diğer parametrelerin karşılaştırılması tablo 3'te gösterilmiştir. Bu analizde EPC sayıları grup A'da grup B'ye oranla daha az bulunsa da, farklılık istatistiksel anlamlılığa ulaşmamıştır (Tablo 4). STEMI tanısı alan hastalar bir grup olarak değerlendirilip $(n=35)$, diğer akut koroner sendromlu hastalar ile kıyaslandığında EPC sayısı açısından fark bulunmamıştır (Tablo 5). Koroner anjiografide normal koroner arterler saptanan hastalar ile koroner arterlerinde aterosklerotik lezyonu olan hastalar EPC sayısı açısından kıyaslandığında anlamlı fark bulunmamıştır (Tablo 6).

Tablo 3. Bazal karakteristik özellikler.

\begin{tabular}{|c|c|c|c|c|c|c|}
\hline & & \multicolumn{2}{|c|}{$\begin{array}{l}\text { Grup A* } \\
(n=41)\end{array}$} & \multicolumn{2}{|c|}{$\begin{array}{l}\text { Grup B** } \\
(\mathbf{n}=\mathbf{8 4})\end{array}$} & $\mathbf{P}$ \\
\hline Yaş (Y1l) & & \multicolumn{2}{|c|}{$55,66 \pm 10,29$} & \multicolumn{2}{|c|}{$57,99 \pm 10,92$} & 0,256 \\
\hline Cinsiyet (K/E) & & \multicolumn{2}{|c|}{$12 / 29$} & \multicolumn{2}{|c|}{$22 / 62$} & 0,882 \\
\hline \multirow[t]{3}{*}{$\mathrm{HT}$} & & $\mathrm{n}$ & $\%$ & n & $\%$ & \\
\hline & Yok & 20 & 48,78 & 45 & 53,57 & \multirow{2}{*}{0,755} \\
\hline & Var & 21 & 51,22 & 39 & 46,43 & \\
\hline \multirow[t]{2}{*}{$\mathrm{DM}$} & Yok & 30 & 73,17 & 63 & 75 & \multirow{2}{*}{0,999} \\
\hline & Var & 11 & 26,83 & 21 & 25 & \\
\hline HsCRP & & \multicolumn{2}{|c|}{$1,23 \pm 2,15$} & \multicolumn{2}{|c|}{$2,04 \pm 2,31$} & 0,063 \\
\hline HDL & & \multicolumn{2}{|c|}{$35,59 \pm 8,13$} & \multicolumn{2}{|c|}{$32,07 \pm 8,60$} & 0,031 \\
\hline LDL & & \multicolumn{2}{|c|}{$105,32 \pm 38,73$} & \multicolumn{2}{|c|}{$124,86 \pm 40,16$} & 0,011 \\
\hline Trigliserit & & \multicolumn{2}{|c|}{$148,49 \pm 82,35$} & \multicolumn{2}{|c|}{$170,58 \pm 111,22$} & 0,214 \\
\hline Fibrinojen & & \multicolumn{2}{|c|}{$319,13 \pm 122,53$} & \multicolumn{2}{|c|}{$330,18 \pm 116,83$} & 0,626 \\
\hline \multirow[t]{3}{*}{ Sigara kullanma } & & $\mathbf{n}$ & $\%$ & $\mathbf{n}$ & $\%$ & \\
\hline & İçmeyen & 20 & 48,78 & 39 & 46,43 & \multirow{2}{*}{0,955} \\
\hline & İçen & 21 & 51,22 & 45 & 53,57 & \\
\hline Gensini skorlaması & & \multicolumn{2}{|c|}{$16,14 \pm 20,82$} & \multicolumn{2}{|c|}{$45,53 \pm 30,48$} & $\mathbf{0}$ \\
\hline EF & & \multicolumn{2}{|c|}{$56,73 \pm 11,49$} & \multicolumn{2}{|c|}{$46,57 \pm 11,42$} & $\mathbf{0}$ \\
\hline LVDSÇ & & \multicolumn{2}{|c|}{$4,66 \pm 0,52$} & \multicolumn{2}{|c|}{$4,85 \pm 0,55$} & 0,063 \\
\hline Sedimentasyon & & \multicolumn{2}{|c|}{$18,22 \pm 20,01$} & \multicolumn{2}{|c|}{$25,99 \pm 21,08$} & 0,051 \\
\hline \multirow[t]{3}{*}{ Statin kullanma } & & $\mathbf{n}$ & $\%$ & n & $\%$ & \\
\hline & Yok & 28 & 68,29 & 52 & 61,9 & \multirow{2}{*}{0,617} \\
\hline & Var & 13 & 31,71 & 32 & 38,1 & \\
\hline \multirow[t]{2}{*}{ ACE inhibitörü / ARB kullanımı } & Yok & 29 & 70,73 & 51 & 60,71 & 370 \\
\hline & Var & 12 & 29,27 & 33 & 39,29 & 0,370 \\
\hline
\end{tabular}

HT: Hipertansiyon, DM: Diyabetes mellitus, HsCRP: Yüksek duyarlılıklı C reaktif protein, HDL: Yüksek dansiteli lipoprotein, LDL: Düşük dansiteli lipoprotein, EF: Ejeksiyon fraksiyonu, LVDSÇ: sol ventrikül diyastol sonu çapı.

* Marker (-), ** Marker (+).Veriler ortalama \pm standart sapma olarak gösterilmektedir. 
Tablo 4. Endotelyal progenitör hücre sayısının biyomarker yükselmesi olan ve olmayan gruplar arasında karşılaştırılması.

\begin{tabular}{lll}
\hline \multicolumn{1}{c}{ Grup A* $(\mathbf{n}=\mathbf{4 1})$} & Grup B** $(\mathbf{n}=\mathbf{8 4})$ & $\mathbf{P}$ \\
\hline EPC $3,89 \pm 2,91$ & $4,80 \pm 5,22$ & 0,302 \\
\hline$*$ Marker $(-), * *$ Marker $(+)$ & & \\
\hline $\begin{array}{l}\text { EPC: Endotelyal progenitör hücre. Veriler ortalama } \pm \text { standart sapma } \\
\text { olarak gösterilmektedir. }\end{array}$ & \\
\hline
\end{tabular}

Tablo 5. Endotelyal progenitör hücre sayısının STEMI ve diğer akut koroner sendromlu hastalar arasında karşılaştırılması.

\begin{tabular}{lllll}
\hline \multicolumn{1}{c}{ Grup A* $(\mathbf{n = 3 5})$} & Grup B** $(\mathbf{n = 9 0})$ & $\mathbf{F}$ & $\mathbf{P}$ \\
\hline EPC & $3,87 \pm 2,74$ & $4,74 \pm 5,14$ & 1,683 & 0,225 \\
\hline EPC: & Endotelyal progenitör hücre. * STEMI, ** Diğer akut koroner \\
sendromu. Veriler ortalama \pm standart sapma olarak gösterilmektedir.
\end{tabular}

Tablo 6. Endotelyal progenitör hücre sayısının normal koroner arterleri olan ve olmayan hastalar arasında karşılaştırılması.

\begin{tabular}{lllll}
\hline & Grup A* $(\mathbf{n}=\mathbf{1 3})$ & Grup B** $(\mathbf{n = 1 1 2})$ & $\mathbf{F}$ & $\mathbf{P}$ \\
\hline EPC & $3,76 \pm 2,94$ & $4,58 \pm 4,76$ & 0,874 & 0,389 \\
\hline EPC: & Endotelyal progenitör hücre. * Normal koroner & arterler, $* *$ & Koroner \\
aterosklerotik lezyon saptanan hastalar. & & \\
Veriler ortalama \pm standart sapma olarak gösterilmektedir.
\end{tabular}

\section{Tartıșma}

Biz bu çalışmada hastalarımızı akut koroner sendrom tanısı ile koroner yoğun bakım ünitesine yatırılan hastalar arasından seçtik ve çalışmayı iki aşamada analiz ettik. İlk aşamada akut koroner sendrom sınıflamasında yer alan üç alt grup arasında EPC sayıları açısından fark olup olmadığını araştırdık. İkinci aşamada ise kardiyak hasar gelişmiş hastalar ile gelişmemiş olanlar arasında EPC sayıları açısından fark olup olmadığını inceledik. Koroner arter hastalığının bu akut faz grupları arasında EPC sayıları açısından fark aradığımızdan gruplar arasında EPC sayılarını etkileyebilecek diğer parametreler de göz önünde bulunduruldu. Daha önce yapılan klinik çalışmalarda EPC sayıları ve fonksiyonlarının çeşitli kardiyovasküler hastalıklar, risk faktörleri ve medikal yaklaşımlar ile ilişkileri incelenmiştir. HT, DM, hiperlipidemi ve sigara içimi gibi kardiyovasküler risk faktörlerinin koroner arter hastalığı gelişiminden bağımsız olarak EPC sayılarını azalttığı gösterilmiştir [9, 11, 12, 20-29]. İleri yaş EPC sayı ve fonksiyonlarında azalmaya neden olurken [7], fiziksel egzersiz bu hücrelerin sayı ve işlevsel kabiliyetlerini artırmaktadır [30-32]. EPC sayılarının stabil koroner arter hastalığı hastalarında azalmışken [33], STEMI [34] ve USAP [35] hastalarında yani hastalığın akut sürecinde arttığ belirlenmiştir. Medikal tedavi yaklaşımlarından statin, ACE inh/ARB, eritropoetin, roziglitazon kullanımının da EPC sayılarında artışa neden olduğu ve östrojen düzeyleri ile EPC sayıları arasında pozitif korelasyon olduğu daha önce yapılan klinik çalışmalarla ortaya konmuştur [36-43].

Çalışmanın birinci aşamasında daha önce EPC sayılarının arttığı saptanan akut koroner sendrom alt gruplarında EPC sayıları bakımından fark olup olmadığı incelenmiştir. Bu amaçla EPC sayısı üzerinde etkisi olan diğer bağımsız değişkenlerin de gruplar arasında karşılaştırılması yapılmıştır. Daha önce ileri yaşın EPC sayıları üzerinde olumsuz etkilerinin olduğu gösterilmişti [10]. Üç grup arasında yaş açısından istatistiksel olarak anlamlı fark bulunmamıştır. Yine EPC sayılarını azaltan bir diğer bağımsız faktör olan HT açısından da gruplar arasında fark yoktu. DM açısından yapılan karşılaştırmada ise STEMI hastalarında diğer gruplara göre anlamlı olarak daha az sıklıkta DM gözlendiği saptanmıştır. Bu bulgu EPC sayısını etkileyen bir parametre olarak gruplar arasında 
olumsuz bir gösterge olsa da diğer EPC sayısı üzerinde etkili faktörler olan sigara kullanımı, statin kullanımı, ACE inh/ARB kullanımı ve serum LDL ve trigliserit düzeyleri açısından üç grup arasında istatistiksel olarak anlamlı fark saptanmamıştır.

İnflamatuar bir süreç olan aterosklerozda akut koroner sendrom ile başvuran hastaların inflamasyon belirteçleri açısından değerlendirilmesi amacı ile gruplar arasında fibrinojen, yüksek duyarlılıklı $\mathrm{C}$ reaktif protein (hs-CRP) ve sedimentasyon değerleri de karşılaştırılmıştır. Bu amaçla yapılan değerlendirmede üç grup arasında sedimentasyon ve fibrinojen değerleri arasında fark saptanmazken, hs-CRP değerinin STEMI grubunda USAP grubuna göre anlamlı olarak daha yüksek olduğu belirlenmiştir. Hs-CRP koroner arter hastalığının önemli öngörücülerinden biridir ve bu bulgu STEMI hastalarında USAP hastalarına göre daha fazla aterosklerotik yük ve akut fazda daha fazla inflamatuar süreç beklentisi ile açıklanabilir. Çalışmada ayrıca koroner aterosklerotik yük belirlenmesi amacıyla gruplar arasında koroner anjiografi sonrası Gensini skorlaması yapılmış ve USAP grubunda STEMI ve NSTEMI gruplarına göre istatistiksel olarak anlamlı düzeyde daha düşük bulunmuştur. Bu bulgu ile beraber hs-CRP değerinde de benzer verilerin elde edilmesi, USAP grubunda aterosklerotik yükün diğer gruplara oranla daha az olduğunu göstermektedir.

Yapılan istatistiksel değerlendirmede STEMI, NSTEMI ve USAP grupları arasında EPC sayıları açısından anlamlı fark bulunmamıştır. Daha önce yapılan çalışmalarda da bu üç alt grup birbiriyle kıyaslanmamakla birlikte ayrı ayrı olarak değerlendirildiğinde bu hastalarda EPC sayılarının sağlıklı popülasyonlara göre arttığı saptanmıştır [33-35]. Dolayısıyla sağlıklı popülasyon ile değil de birbirleriyle kıyaslanan bu gruplar arasında EPC sayıları açısından fark olmaması beklenen bir bulgu olabilir.

Çalışmanın ikinci aşamasında ise USAP öntanısı ile hospitalize edilen fakat enzim yüksekliği olmayan koroner anjiografi ve ekokardiyografileri normal saptanan 13 hasta daha değerlendirildi. Hastalar enzim yüksekliği saptanmayan, yani kardiyak hasarın olmadığı USAP hastaları ve koroner anjiografide normal koroner arterler saptanan hastalar bir grup, kardiyak enzim yüksekliği saptanan yani kardiyak hasarın dökümante olduğu STEMI ve NSTEMI hastaları diğer bir grup olmak üzere iki gruba ayrıldı ve bu iki grup arasında EPC sayıları açısından fark olup olmadığına bakıldı. Yine ilk olarak EPC sayılarını etkileyen diğer faktörler iki grup arasında karşılaştırıldı. Yaş, DM varlığı, HT varlığı, sigara kullanımı, serum trigliserit düzeyleri, statin ve ACE inh/ARB kullanımı açısından iki grup arasında istatistiksel olarak anlamlı fark saptanmadı. Serum LDL seviyeleri ise grup A'da anlamlı olarak daha düşük saptandı. Fibrinojen, sedimentasyon ve hs-CRP düzeyleri açısından iki grup arasında istatistiksel olarak anlamlı fark saptanmadı. Gensini skorlamasında grup A'daki değerler grup B'ye göre anlamlı olarak daha düşük saptandı. STEMI ve NSTEMI grubundaki hastaların aterosklerotik yüke bağlı olarak daha yüksek Gensini skoruna sahip olacağı beklenen bir bulgu idi. Yine beklendiği üzere ejeksiyon fraksiyonu STEMI ve NSTEMI hastalarının bulunduğu grup B'de grup A'ya oranla anlamlı olarak daha düşük saptandı. Diğer etkenler bu şekilde kıyaslandıktan sonra kardiyak hasarın mevcudiyeti açısından birbirinden ayrılan grup A ve grup B arasında EPC sayıları açısından anlamlı fark saptanmadı. Daha önceki çalışmalarda EPC sayılarının kronik aterosklerotik hastalık sürecinde düştüğü akut koroner sendrom fazında ise yükseldiği gösterilmişti. USAP hastalarında kardiyak enzim yüksekliği olmamasına rağmen EPC sayılarında artış olduğu yine yapılan klinik çalışmalar ile belirlenmişti [3335]. [35]. Bu çalışmada grup A'da (USAP ve Normal Koroner Arterler) EPC sayıları grup B'ye (STEMI ve NSTEMI) oranla daha az bulunsa da fark, istatistiksel anlamlılığa ulaşmamıştır. Daha önceden akut dönemde EPC sayısının arttığ1 gösterilen USAP hastalarının grup A içinde değerlendirilmesi EPC sayılarının daha düşük saptanmasına rağmen istatistiksel anlamını yitirmesine neden olabilir.

Çalışmamız bazı kısıtlılıklara sahiptir. Değerlendirilen hasta sayısı daha fazla olabilirdi. Daha büyük bir hasta popülasyonunun incelenmesi anlama ulaşmayan istatistiksel eğilimlerin anlama ulaşmasını sağlayabilir. Diğer yandan biz bu çalışmada EPC'nin 
sadece sayısı üzerinde yorumlar yaptık. Rejenerasyon kapasitesi açısından sayının yanında bu hücrelerin fonksiyonel kapasiteleri de değerlendirilebilirdi. Çünkü bilindiği üzere bu hücrelerin hasarlı dokudaki onarım işlevleri sayısal değerlerinin yanında kemik iliğinde yapım, kemik iliğinden salınım, hedef dokuya göç etme, hedef dokuya yerleşme (homing) gibi özelliklerinin de yeterli düzeyde olması ile bir bütün olarak değerlendirilmelidir. Ayrıca bu hücrelerin sayı ve fonksiyonlarını etkileyen bazı sitokinlerin, reseptörlerin ve büyüme faktörlerinin de incelenmesi verilerin daha güçlü yorumlanmasını sağlayabilirdi. Öte yandan koroner anjiografide normal koroner arterler olarak raporlanan hastalar kardiyak risk faktörleri ile kardiyak sendrom-X veya koroner anjiografinin tanımlayamadığı ancak intravasküler ultrason ile belirlenebilecek koroner arter hastalığına sahip olabilirler.

Sonuç olarak; bu çalışmanın amacı akut koroner sendrom ile başvuran hastalarda hastalığın alt grupları arasında EPC sayıları açısından fark olup olmadığının incelenmesi idi. Böylece tedavi yaklaşımları içerisinde gündeme gelen bu hücrelerin, hastalığın ciddiyeti ile arasındaki ilişkinin saptanması ve henüz rutin klinik kullanıma girmeyen ancak çalışmalar bazında üzerinde yoğunlaşılan tedavi amaçlı kullanımı konusunda aydınlatıcı veriler elde edilmesini sağlayabilirdi. Çalışma bulgularımız, daha önce ayrı ayrı akut koroner sendrom alt tipleri ile sağlıklı popülasyona veya stabil koroner arter hastalığına göre kıyaslandığında sayılarının arttığı belirlenen bu hücrelerin STEMI, NSTEMI ve USAP hastalarında birbirlerine oranla sayıca istatistiksel anlamlı farka ulaşmadığını saptamıştır. Bu durum hastalığın akut sürecinde bu hücrelerin sayısındaki artışın hastalığın ciddiyetinden bağımsız olduğu şeklinde yorumlanabilir. Sayıca istatiksel olarak anlamlı fark saptanmasa da endotelya progenitor hücrelerin fonksiyonları hastalığın ciddiyetinden farklı şekilde etkilenmiş olabilir. Yine çalışmanın ikinci aşama analizinde kardiyak enzim yüksekliği; dolayısıyla kardiyak hasar mevcudiyeti saptanan hastalar (STEMI, NSTEMI) ile enzim yüksekliği olmamasından dolayı kardiyak hasar mevcudiyeti saptanmayan hastalar (USAP, Normal Koroner Arterler) arasinda EPC sayıları açısından anlamlı fark bulunmamıştır. Bu bulgular yine yukarıda belirttiğimiz gibi hastalığın ciddiyeti ile hücre sayısındaki artış arasında anlamlı bir ilişki olamadığı görüşünü desteklemektedir. Bütün bunlar, en az hücre sayıları kadar hücre fonksiyonlarını ve bu hücrelerin hedef dokularla etkileşimini inceleyen ileri araştırmaların gerekliliğine işaret etmektedir. Bu bilgiler sşığında tedavi yöntemlerindeki gelişmelere rağmen halen tedavi direnci sorununun gündemde olduğu koroner arter hastalığında, bu hücrelerin terapötik yaklaşımlarda kullanılması için kemik iliğinde ve periferik kandaki sayı ve fonksiyonları, hedef dokudaki etkileri ve bu hücreleri etkileyen düzenleyici faktörler konusunda daha ileri klinik çalışmalara ihtiyaç duyulmaktadır. Ayrıca izole edilmeleri ve dolayısıyla hedef dokuya optimal düzeyde penetrasyonu oldukça zor olan bu hücrelerin elde edilmeleri ve klinik kullanımda veriliş yolları ile ilgili yapılacak araştırmalar şu anda maliyet-etkin gibi görünmeyen bu tedavi yaklaşımının uygulanabilirliği konusunda aydınlatıcı olacaktır.

\section{Kaynaklar}

1. Hennekens $\mathrm{CH}$. Risk factors for coronary heart disease in women. Cardiol Clin 1998; 16: 1-8.

2. Onat A, Sansoy V, Soydan İ, Tokgözoğlu L, Adalet K. TEKHARF Oniki yıllık izlenimlerine göre Türk eriskinlerinde kalp sağlıgı. Argos iletisim hizmetleri reklamc1lık ve ticaret AŞ. Temmuz İstanbul-2003.

3. Sans S, Kesteloot H, Kromhout D. The burden of cardiovascular diseases mortality in Europe. Task Force of the European Society of Cardiology on Cardiovascular Mortality and Morbidity Statistics in Europe. Eur Heart J 1997; 18: $1231-48$.

4. Ross R, Glomset J, Harker L. Response to injury and atherogenesis. Am J Pathol 1977; 86: 675-84.

5. Gulati R, Jevremovic D, Peterson TE, Witt TA, Kleppe LS, Mueske CS, Lerman 
A, Vile RG, Simari RD. Autologous culture-modified mononuclear cells confer vascular protection after arterial injury. Circulation 2003; 108: 1520-6.

6. He T, Smith LA, Harrington S, Nath KA, Caplice NM, Katusic ZS. Transplantation of circulating endothelial progenitor cells restores endothelial function of denuded rabbit carotid arteries. Stroke 2004; 35: 2378-84.

7. Rauscher FM, Goldschmidt-Clermont PJ, Davis BH, Wang T, Gregg D, Ramaswami P, Pippen AM, Annex BH, Dong C, Taylor DA. Aging, progenitor cell exhaustion, and atherosclerosis. Circulation 2003; 108: 457-63.

8. Wassmann $\mathrm{S}$, Werner $\mathrm{N}$, Czech $\mathrm{T}$, Nickenig $\mathrm{G}$. Improvement of endothelial function by systemic transfusion of vascular progenitor cells. Circ Res 2006; 99: e74-83.

9. Vasa M, Fichtlscherer S, Aicher A, Adler K, Urbich C, Martin H, Zeiher AM, Dimmeler S. Number and migratory activity of circulating endothelial progenitor cells inversely correlate with risk factors for coronary artery disease. Circ Res 2001; 89: E1-E7.

10. Fadini GP, Coracina A, Baesso I, Agostini C, Tiengo A, Avogaro A, de Kreutzenberg SV. Peripheral blood CD34+KDR+ endothelial progenitor cells are determinants of subclinical atherosclerosis in a middle-aged general population. Stroke 2006; 37: 2277-82.

11. Zhu S, Liu X, Li Y, Goldschmidt-Clermont PJ, Dong C. Aging in the Atherosclerosis Milieu May Accelerate the Consumption of Bone Marrow Endothelial Progenitor Cells. Arterioscler Thromb Vasc Biol 2007; 27: 113-9.

12. Thijssen DH, Vos JB, Verseyden C, van Zonneveld AJ, Smits P, Sweep FC, Hopman MT, de Boer HC. Haematopoietic stem cells and endothelial progenitor cells in healthy men: effect of aging and training. Aging Cell 2006; 5: 495-503.

13. Daub K, Langer H, Seizer $P$, Stellos K, May AE, Goyal P, Bigalke B, Schönberger T, Geisler T, Siegel-Axel D, Oostendorp RA, Lindemann S, Gawaz M. Platelets induce differentiation of human CD34+ progenitor cells into foam cells and endothelial cells. FASEB J 2006; 20: 2559-61.

14. Nonaka-Sarukawa M, Yamamoto K, Aoki H, Nishimura Y, Tomizawa H, Ichida M, Eizawa T, Muroi K, Ikeda U, Shimada K. Circulating endothelial progenitor cells in congestive heart failure. Int J Cardiol 2007; 119: 344-8.

15. Güven H, Shepherd RM, Bach RG, Capoccia BJ, Link DC. The number of endothelial progenitor cell colonies in the blood is increased in patients with angiographically significant coronary artery disease. J Am Coll Cardiol 2006; 48: 1579-87.

16. Boos CJ, Lip GY, Blann AD. Circulating endothelial cells in cardiovascular disease. J Am Coll Cardiol 2006; 48: 1538-47.

17. Hill JM, Zalos G, Halcox JP, Schenke WH, Waclawiw MA, Quyyumi AA, Finkel T. Circulating endothelial progenitor cells, vascular function, and cardiovascular risk. N Engl J Med 2003; 348: 593-600.

18. Körbling M, Reuben JM, Gao H, Lee BN, Harris DM, Cogdell D, Giralt SA, Khouri IF, Saliba RM, Champlin RE, Zhang W, Estrov Z. Recombinant human granulocyte-colony-stimulating factor-mobilized and apheresis-collected endothelial progenitor cells: a novel blood cell component for therapeutic vasculogenesis. Transfusion 2006; 46: 1795-802.

19. Gensini GG. A more meaningful scoring system for determining the severity of coronary heart disease. Am J Cardiol 1983; 51: 606.

20. Chen JZ, Zhang FR, Tao QM, Wang XX, Zhu JH, Zhu JH. Number and activity of endothelial progenitor cells from peripheral blood in patients with hypercholesterolaemia. Clin Sci 2004; 107: 273-80.

21. Chen YH, Lin SJ, Lin FY, Wu TC, Tsao CR, Huang PH, Liu PL, Chen YL, Chen JW. High glucose impairs early and late endothelial progenitor cells by modifying nitric oxide-related but not oxidative stress-mediated mechanisms. Diabetes 2007; 56: 1559-68. 
22. Imanishi T, Hano T, Nishio I. Angiotensin II potentiates vascular endothelial growth factor-induced proliferation and network formation of endothelial progenitor cells. Hypertens Res 2004; 27: 101-8.

23. Kondo T, Hayashi M, Takeshita K, Numaguchi Y, Kobayashi K, Iino S, Inden Y, Murohara T. Smoking cessation rapidly increases circulating progenitor cells in peripheral blood in chronic smokers. Arterioscler Thromb Vasc Biol 2004; 24 : 1442-7.

24. Kränkel N, Adams V, Linke A, Gielen S, Erbs S, Lenk K, Schuler G, Hambrecht R. Hyperglycemia reduces survival and impairs function of circulating bloodderived progenitor cells. Arterioscler Thromb Vasc Biol 2005; 25: 698-703.

25. Laufs U, Wassmann S, Czech T, Münzel T, Eisenhauer M, Böhm M, Nickenig G. Physical inactivity increases oxidative stress, endothelial dysfunction, and atherosclerosis. Arterioscler Thromb Vasc Biol 2005; 25: 809-14.

26. Loomans CJ, de Koning EJ, Staal FJ, Rookmaaker MB, Verseyden C, de Boer HC, Verhaar MC, Braam B, Rabelink TJ, van Zonneveld AJ. Endothelial progenitor cell dysfunction: a novel concept in the pathogenesis of vascular complications of type 1 diabetes. Diabetes 2004; 53: 195-9.

27. Scheubel RJ, Zorn H, Silber RE, Kuss O, Morawietz H, Holtz J, Simm A. Agedependent depression in circulating endothelial progenitor cells in patients undergoing coronary artery bypass grafting. J Am Coll Cardiol 2003; 42: 207380.

28. Tepper OM, Galiano RD, Capla JM, Kalka C, Gagne PJ, Jacobowitz GR, Levine JP, Gurtner GC. Human endothelial progenitor cells from type II diabetics exhibit impaired proliferation, adhesion, and incorporation into vascular structures. Circulation 2002; 106: 2781-6.

29. Wang X, Zhu J, Chen J, Shang Y. Effects of nicotine on the number and activity of circulating endothelial progenitor cells. J Clin Pharmacol 2004; 44: 881-9.

30. Van Craenenbroeck EM, Vrints CJ, Haine SE, Vermeulen K, Goovaerts I, Van Tendeloo VF, Hoymans VY, Conraads VM. A maximal exercise bout increases the number of circulating CD34+/KDR+ endothelial progenitor cells in healthy subjects. Relation with lipid profile. J Appl Physiol 2008; 104: 1006-13.

31. Rehman J, Li J, Parvathaneni L, Karlsson G, Panchal VR, Temm CJ, Mahenthiran J, March KL. Exercise acutely increases circulating endothelial progenitor cells and monocyte-/macrophage-derived angiogenic cells. J Am Coll Cardiol 2004; 43: 2314-8.

32. Steiner S, Niessner A, Ziegler S, Richter B, Seidinger D, Pleiner J, Penka M, Wolzt M, Huber K, Wojta J, Minar E, Kopp CW. Endurance training increases the number of endothelial progenitor cells in patients with cardiovascular risk and coronary artery disease. Atherosclerosis 2005; 181: 305-10.

33. Heeschen C, Lehmann R, Honold J, Assmus B, Aicher A, Walter DH, Martin H, Zeiher AM, Dimmeler S. Profoundly reduced neovascularization capacity of bone marrow mononuclear cells derived from patients with chronic ischemic heart disease. Circulation 2004; 109: 1615-22.

34. Massa M, Rosti V, Ferrario M, Campanelli R, Ramajoli I, Rosso R, De Ferrari GM, Ferlini M, Goffredo L, Bertoletti A, Klersy C, Pecci A, Moratti R, Tavazzi L. Increased circulating hematopoietic and endothelial progenitor cells in the early phase of acute myocardial infarction. Blood 2005; 105: 199-206.

35. George J, Goldstein E, Abashidze S, Deutsch V, Shmilovich H, Finkelstein A, Herz I, Miller H, Keren G. Circulating endothelial progenitor cells in patients with unstable angina: association with systemic inflammation. Eur Heart J 2004; 25: 1003-8.

36. Dimmeler S, Aicher A, Vasa M, Mildner-Rihm C, Adler K, Tiemann M, Rütten H, Fichtlscherer S, Martin H, Zeiher AM. HMG-CoA reductase inhibitors (statins) increase endothelial progenitor cells via the PI 3-kinase/Akt pathway. J Clin Invest 2001; 108: 391-7. 
37. Iwakura A, Luedemann C, Shastry S, Hanley A, Kearney M, Aikawa R, Isner JM, Asahara T, Losordo DW. Estrogen-mediated, endothelial nitric oxide synthase-dependent mobilization of bone marrow-derived endothelial progenitor cells contributes to reendothelialization after arterial injury. Circulation 2003; 108: 3115-21.

38. Pellegatta F, Bragheri M, Grigore L, Raselli S, Maggi FM, Brambilla C, Reduzzi A, Pirillo A, Norata GD, Catapano AL. In vitro isolation of circulating endothelial progenitor cells is related to the high density lipoprotein plasma levels. Int J Mol Med 2006; 17: 203-8.

39. Strehlow K, Werner N, Berweiler J, Link A, Dirnagl U, Priller J, Laufs K, Ghaeni L, Milosevic M, Böhm M, Nickenig G. Estrogen increases bone marrow-derived endothelial progenitor cell production and diminishes neointima formation. Circulation 2003; 107: 3059-65.

40. Vasa M, Fichtlscherer S, Adler K, Aicher A, Martin H, Zeiher AM, Dimmeler S. Increase in circulating endothelial progenitor cells by statin therapy in patients with stable coronary artery disease. Circulation 2001; 103: 2885-90.

41. Walter DH, Rittig K, Bahlmann FH, Kirchmair R, Silver M, Murayama T, Nishimura H, Losordo DW, Asahara T, Isner JM. Statin therapy accelerates reendothelialization: a novel effect involving mobilization and incorporation of bone marrow-derived endothelial progenitor cells. Circulation 2002; 105: 3017 24.

42. Werner N, Priller J, Laufs U, Endres M, Böhm M, Dirnagl U, Nickenig G. Bone marrow-derived progenitor cells modulate vascular reendothelialization and neointimal formation: Effect of 3-hydroxy-3-methylglutaryl coenzyme a reductase inhibition. Arterioscler Thromb Vasc Biol 2002; 22: 1567-72.

43. Bahlmann FH, de Groot K, Mueller O, Hertel B, Haller H, Fliser D. Stimulation of endothelial progenitor cells: a new putative therapeutic effect of angiotensin II receptor antagonists. Hypertension 2005; 45: 526-9. 